\title{
Development of Electronic Money and Its Impact on the Central Bank Role and Monetary Policy
}

\author{
Mohamad Al-Laham and \\ Haroon Al-Tarawneh \\ Albalqa Applied University, \\ Karak, Jordan
}

Laham1st@yahoo.com; haroon@teacher.com

\author{
Najwan Abdallat \\ The Arab Academy for Banking \\ and Financial Sciences, \\ Amman, Jordan
}

najwan sultan@yahoo.com

\begin{abstract}
In recent years there has been considerable interest in the development of electronic money schemes. Electronic money has the potential to take over from cash as the primary means of making small-value payments and could make such transactions easier and cheaper for both consumers and merchants. Electronic money is a record of the funds or "value" available to a consumer stored on an electronic device in his or her possession, either on a prepaid card or on a personal computer for use over a computer network such as the Internet. This paper argues that emoney, as a network good, could become an important form of currency in the future. Such a development would influence the effectiveness and implementation of monetary policy. If an increased use of e-money substantially limits demand for central bank reserves, it would require changes in the operational target of the central bank and a closer coordination of monetary and fiscal polic ies.
\end{abstract}

Ke ywords: Electronic purse, Monetary aggregate, Money laundering, Open market sales, Smart card, Electronic money.

\section{Introduction}

The development of information technology and the emerging of a number of new innovations are taking place in the area of retail payments known as electronic money (e-money).This development influencing the banking industry due to the increased use of pre-paid card, e-purse, and ewires of money orders, e-banking, e-loans.

These innovations have the potential to challenge the predominant role of cash for making smallvalue payments and could make retail transactions easier and cheaper for consumers and merchants. However, they also raise a number of policy issues for central banks because of the possi-

Material published as part of this publication, either on-line or in print, is copy righted by the Informing Science Institute. Permission to make digital or paper copy of part or all of these works for personal or classroom use is granted without fee provided that the copies are not made or distributed for profit or commercial advantage AND that copies 1) bear this notice in full and 2) give the full citation on the first page. It is permissible to abstract these works so long as cred it is given. To copy in all other cases or to republish or to post on a server or to redistribute to lists requires specific permission and payment of a fee. Contact Publisher@InformingScience.org to request redistribution permission. ble implications for central bank and monetary policy and because of central banks' general interest in payment systems. This paper provides a definition of electronic money and a description of its key features. It discusses the factors influencing the development of e-money products. Finally, it reviews the policy issues raised by e-money developments, as seen from a central bank perspective, 
and discusses the possible policy responses and try to answer the following question: would Emoney development affect central bank role and monetary policy?

\section{Problem of the Study}

"The term [electronic] money refers to various proposed electronic payment mechanisms designed for use by consumers to make retail payments. Digital money products have the potential to replace central bank currency" (Berentsen, 1997). This quote indicates that the advent of electronic money will have an impact on the banking system and monetary policy. While this topic is controversial it seems obvious that some changes will result and that there is no prefect answer to predict this new instruments affect on monetary aggregates and the role of central banks. Its growth will be based on many things: future technology, increased security, regulation, and ease of conversion. It can impact such variables as monetary supply, exchange rates, the money multiplier, velocity of money and seignorage. Increased reliance on electronic money as a substitute for currency will directly affect the central bank and its control over monetary aggregates and policies.

\section{Purpose of the Study}

This paper will focus on the development of electronic money and its impact on the central bank role and monetary policy. Here the focus is primarily on the forces sustaining the development of e-money and on the central bank ability to conduct monetary policy in the presence of e-money.

The purpose of the paper aims at discussing the following issues:

1- Does electronic money considered as a form of ins ide money similar to private notes issued by free banks?

2- If this is the case, does this situation challenge the control of the central bank over the supply of money? In other words will the monetary policy still be efficient?

\section{Methodology of the Study}

This paper depends on analytical method at determining the impact of the development of electronic money in the different areas related directly or indirectly to the emerging of this new innovation at the last decade. In this paper we incentive our effort at analyzing the previous literature review related to this subject to make better understanding to all aspects of this subject depending on a judgment approach which represent our persuasive in this field to determine the most influenced areas to obtain the best conclusions and give the appropriate recommendations to convene our results.

\section{Definition of Electronic Money}

Electronic money is the money balance recorded electronically on a "stored-value" card (Ely, 1996). These cards, "smart cards," have a microprocessor embedded which can be loaded with a monetary value. Another form of electronic money is network money, "software that allows the transfer of value on computer networks, particularly the internet. Like a travelers check, a digital money balance is a floating claim on a private bank or other financial institution that is not linked to any particular account" (Berentsen, 1997). This money is issued by both public and private institutions worldwide and is raising concern about the future ability of central banks to set money supply targets. It is widely used in such places as "Germany, the Netherlands, Belgium, Singapore, and Hong Kong" (Tak, 2002). 
E-money as just defined differs from so-called access products, which are products that allow consumers to use electronic means of communication to access otherwise conventional payment services (for example, use of a standard personal computer and a computer network such as the Internet to make a credit card payment or to transmit instructions to make funds transfers between bank accounts). The signif icant novel feature of these access schemes is the communication method (e.g. the use of a computer network rather than a visit to a bank branch) and so, although they are of interest, they do not raise the same concerns as e-money schemes and are not considered further in this report.

\section{Key Features of E-money Schemes}

Various e-money schemes are being developed and they differ considerably in their features, many aspects of which are still to be finalized (Bernkopf, 1998). Firstly, e-money products differ in their technical implementation. To store the prepaid value, card-based schemes involve a specialized and portable computer hardware device, typically a microprocessor chip embedded in a plastic card, while software-based schemes use specialized software installed on a standard personal computer.

Secondly, institutional arrangements may vary. Typically, four types of service provider will be involved in the operation of an e-money scheme: the issuers of the e-money value, the network operators, the vendors of specialized hardware and software and the clearers of e-money transactions.

Thirdly, products differ in the way in which value is transferred. Some e-money schemes allow transfers of electronic balances directly from one consumer to another without any involvement of a third party such as the issuer of the electronic value. Fourthly, related to transferability is the extent to which transactions are recorded. Most schemes register some details of transactions between consumers and merchants in a central database, which could then be monitored. In cases where direct consumer-to-consumer transactions are allowed, these can only be recorded on consumers' own storage devices and can be monitored centrally only when the consumer contacts the e-money scheme operator.

Finally, in most e-money schemes currently being developed or pilot-tested, the "value" stored on the devices is denominated only in the national currency. It is possible, however, for balances to be held and payments to be made in several different national currencies.

\section{Regulatory Issues and Possible Policy Responses to the Development of E-money}

This section first describes the fundamental monetary policy concerns related to the development of electronic money: the need to preserve price stability and the need to preserve the unit-ofaccount function of money. In addition, it lists a number of other factors which also support the introduction of some form of regulation of electronic money issuers. Some of these elements are based on the equivalence, in economic terms, of the issuance of electronic money and deposittaking. While, for the issuer, both represent a source of funds, the customer can use traditional deposits as well as electronic money for payment purposes (Arone, 2004).

\section{Fundamental monetary policy concerns}

If electronic money is issued through the conversion of banknotes or sight deposits, it does not change the money supply and price stability is not endangered. However, if electronic money is issued as a consequence of credit, private issuers have incentives to supply additional amounts of electronic money as long as the difference between the interest charged on the credit and the one paid on electronic money covers the credit risk premium, the provision of the payment service, 
and possibly also the cost of refinancing. Given the low marginal cost of producing electronic money, its issuance could in principle proceed until the interest rate charged on the credit extended for the provision of electronic money is equal to the credit risk premium. This, by lowering the level of interest rates, could in turn endanger the maintenance of price stability.

The risk of overissue would be limited by two factors which increase the costs of issuing electronic money, thereby limiting its supply: first, in a competitive environment, electronic money balances could be remunerated; second, and more importantly, a redeemability requirement could oblige the issuer to possess central bank money. An even stronger measure, which could be considered in the light of future developments in electronic money, would be to introduce a coverage requirement on electronic money, i.e. to request issuers of electronic money to cover part or all of their liabilities with base money. Another way to limit the risk of overissue would be to require rapid clearing of electronic money balances in central bank money.

Thus, it appears that there are several reasons to assume that the risk of overissue of electronic money can be contained. However the issuance of electronic money may have an impact on the conduct of monetary policy.

The question of overissue of electronic money is also related to the question of whether electronic money could endanger the unit-of-account role as incorporated in central bank money. If, in the absence of any regulation, certain electronic money products were to spread at a rapid rate, market views about the creditworthiness of issuers could be affected and electronic money products from different issuers could start to be traded at varying exchange rates. Therefore, the need to preserve the unit-of-account function of money is another argument for imposing a redeemability requirement on electronic money. Such a requirement would guarantee that the role of money in providing a common financial denominator for the whole economy will be maintained.

\section{Efficient functioning of payment systems and confidence in payment instruments}

Another fundamental issue is that the development of electronic money should not endanger the smooth functioning of payment systems. Electronic money offers a technology which permits efficiency gains in the use of payments media to be made. However, this advantage can only be realized if sufficient safeguards are in place to ensure that electronic money is a reliable product accepted by all its users. In particular, float mismanagement, intrus ion of counterfeit value, major technical failure and ultimately the failure of an issuer of electronic money could have a negative impact on the credibility of various electronic money products and possibly even on other cardbased payment products. In addition, the possible increase in the use of electronic money schemes may lead banks to reduce the capacity of their existing conventional payment systems. In such circumstances, the failure of a major issuer could lead to a decline in confidence in electronic money schemes, while it might no longer be possible to revert immediately to more traditional means of payment.

\section{Protection of customers and merchants}

In principle, in a market economy, it is the task of the creditor to assess the creditworthiness of his/her debtor. As regards credit institutions, most customers cannot assess the quality of these institutions due to the asymmetric availability of information and a lack of understanding of the technical security features of the payment systems they offer. This is one of the reasons why a prudential supervisory framework is applied to credit institutions.

Electronic money represents liabilities on the balance sheet of the issuer, created against the provision by customers of cash or scriptural money, which are payable at par to the entities accepting electronic money as payment (the merchants). Therefore, these liabilities represent an asset for 
the customers which can be used for payment purposes. As with deposits, prepayments made to the issuers of electronic money are not left idle but are invested in order to obtain asset returns. As is the case with the value of bank deposits, the value of electronic money could diminish, or even disappear, if the liabilities of the issuer are higher than the value of the assets. Thus, the financial integrity of the issuer would be jeopardized if the investment policy it pursued was not adequately sound. The risks for the issuer are more likely to be triggered by liquidity strains (if assets are liquidated with heavy losses) than by credit risk. Since the issuance of electronic money amounts in economic terms to deposit-taking, the application of a prudential supervisory framework to electronic money issuers would also be justified.

In addition, central banks could be subject to moral hazard problems if economic agents were wrongly to assume that they might support issuers of electronic money financially in order to protect the public's confidence in the currency. It is also possible that some customers will not see clear differences between the protection they receive with traditional bank deposits and the protection they will receive (if any) with prepayments to electronic money issuers.

In the near future it seems unlikely that customers and merchants will hold a large part of their wealth in the form of electronic money, owing, for instance, to the risk of theft or loss. Retailers are also likely to place their takings in a bank account at regular intervals. For these reasons it could be argued that the case for protecting customers and merchants is weakened.

On the other hand, electronic money is designed for everyday use as an alternative to banknotes and coins. If it came to be used widely, it would join cash and sight deposits as a major instrument for transaction purposes. In these circumstances, losses arising from the failure of an issuer might be relatively small for individuals, but quite large in aggregate.

\section{Stability of financial markets}

Since, in practice, customers are unable to assess adequately the creditworthiness of the issuers, there is a risk that customers will have excessive confidence in them until a crisis of confidence occurs, to which they might overreact, triggering bank runs. The history of banking has shown that bank runs are not just a problem for individual depositors and individual deposit-taking institutions, but that they may cause systemic disruptions and may even, ultimately, affect the real economy.

Therefore, the avoidance of systemic risk and consequently the protection of the stability of financial markets have always been a main regulatory concern. Since electronic value loaded on prepaid cards and stored in computer memories is similar in economic terms to bank deposits, there is no reason why the same concerns should not arise to a certain extent with regard to electronic money if it comes to be used in large quantities.

\section{Protection against criminal abuse}

The inadequate management of operational risk and a lack of technical security make an electronic money scheme vulnerable to counterfeit and fraud. If counterfeit money were able to be introduced into the scheme, it could lead to an increase in claims against the issuer which would no longer be backed by the available assets. Thus, the financial integrity of the issuer would be threatened. This vulnerability might be greater for software-based money schemes, which, in general, rely mainly on cryptography, whereas card-based schemes can also use the protection of a tamper-resistant chip.

In the fast developing technical world, the risk of counterfeit and fraud can hardly be excluded. Therefore, if a scheme lacks means detecting counterfeits and fraud, it will not be able to take appropriate counter-measures. This problem is less significant for schemes in which electronic money transactions are processed in a way similar to that in which sight deposits are handled by 
credit institutions. If the scheme is based on a book-entry principle, according to which each loading and, in the end, each payment operation triggers a debit or credit position in the account of the issuer(s), criminal attacks can be detected at an early stage and counter-measures can be taken (Janson, 2004).

By contrast, if electronic money units are transferable from customer to customer without these transactions being subsequently recorded by the issuer or a clearing system, the systems might entail a higher degree of operational risk, since it is not possible to have a complete audit trail of transactions at all times, and the source and exact quantity of any counterfeit electronic money or false value triggered by security deficiencies might not be known. Even those schemes which do not permit customer-to-customer transactions may truncate or amalgamate the data transferred to the issuer or clearing system, which would result in an incomplete audit trail.

Another area of criminal abuse associated with electronic money schemes relates to money laundering and tax evasion. Should electronic money schemes offer the possibility of executing anonymous transfers of large sums of money, they could be increasingly used for such criminal purposes. In fact, it cannot be excluded that market forces alone might foster the development of those schemes whose features are more "attractive" for money laundering purposes (such as anonymity of transactions, the possibility of making customer-to-customer transactions, the impossibility of tracing individual transactions).

\section{Types of Risk Involved in Electronic Money Schemes}

\section{Quantifiable Risks}

1- Credit risk is the risk that a counterpart will fail to perform on an obligation to the institution. It is the most common risk relating to banking activity.

2- Liquidity risk is the risk that the institution is temporarily unable to meet its payment obligations as they fall due without incurring losses.

3- Interest rate risk is the risk that movements in interest rates might adversely affect an institution's financial conditions.

4- Foreign exchange risk is the risk that fluctuations of foreign exchange rates might adversely influence the financial conditions of the institution.

\section{Non-Quantifiable Risks}

1- Strategic risk is the risk that the strategic objectives of an institution, the business strategies developed and the resources devoted to achieving these objectives as well as the quality of its implementation might not be consistent.

2- Operational risk is the risk that deficiencies in internal controls and information systems might result in unexpected losses for the institution.

3- Compliance risk is the risk associated with non-compliance with laws, rules, regulations, prescribed practices or ethical standards.

4- Reputation risk is the risk that the reputation of an institution might deteriorate following specific events.

5- Legal risk is the risk that an institution might be adversely affected by uncertainties surrounding the legal framework governing its operation. This could occur, for instance, in the event that commercial laws are not sufficiently explicit to settle disputes between the issuer and the customer (Crockett, 1998). 


\section{Electronic Money and Its Impact on Central Banking and Monetary Policy}

The increased use of electronic money has lead to various studies about the impact this new form of money could have on central banks' ability to control the money supply. Many economists believe electronic money could completely replace currency while others feel that its impact will be less drastic. The ability to control the money supply depends on the definition of money, M1. M1 currently includes currency, traveler's checks and demand deposits. If the use of these variables were to decrease due to an increased reliance on electronic money, M1 would not serve as an accurate measure of money in the economy. The decreased ability to measure monetary aggregates will limit the central bank's ability to conduct open market operations and target the money supply. This will be offset by the fact that "new digital monies are fully backed by assets such as gold or high-quality financial instruments. Therefore, the need to conduct open market operations will diminish, because the supply of money for transactions should automatically adjust to demand" (Rahn, 2000). If the money supply is assumed to be fixed, "when the currency weight decreases gradually as the use of electronic money increases, the scale of the central bank's assets and liabilities will be reduced, which may lead to a weakening of money management and of the interest rate management through open market operations" (Tak, 2002).

The idea that digital money is commodity based may be overly optimistic. The possibility of fraud could lead the central bank to want to limit the changes to M1 and prevent the growth of electronic money. The following measures could be taken:

- Limit the proliferation of digital money products to prevent the replacement of central bank currency

- Issue digital money products and treat digital money balances in the same way as they do central bank currency

- Apply high reserve requirements on digital money balances

- Absorb the excess liquidity created by appropriate monetary operations (Berentsen, 1997).

These would allow the central bank to maintain control of monetary aggregates though it may do more harm then good by limited technological improvements. Resistance to change may not be the best approach though any acceptance should come with hesitation as a drastic immediate change could cause turmoil in the economy.

The velocity of money is also affected by the increased use of electronic money. An increase in the velocity of money is considered by Rahn to be gradual and requires a compensating adjustment in base money by the Federal Reserve. He feels that the Fed should be able to adjust accordingly as the changes will be "gradual and obvious" (Rahn, 2000). Tak feels that it "will be difficult to measure the resulting changes in velocity because income circulation velocity is calculated from the ratio of a term-end money supply and national income from that period. It is difficult for the circulation velocity resulting from this calculation to reflect effective money flows from electronic settlement properly. Electronic money will inevitably reduce the time and space disposal of expenses of payment settlement transactions, and increases the volume of transactions by promoting transaction convenience" (Tak,2002). It can be seen that the velocity of money will increase if electronic money is first adopted as a major form of money and second added to the aggregates used to compute the velocity of money. Transactions will take place in real time across thousands of miles and transaction costs are greatly reduced causing people to increase the number of transactions made. While increased velocity is a good thing the inability to measure it 
when electronic money is not included in monetary aggregates decreases the central banks ability to control monetary policy.

Electronic money is expected to completely change the character of cross country trade and exchange rates. Due to the ease of transfer of these funds, electronic money denominated in a stronger currency could be preferred and therefore would cause "exchange rate instability, not only giving rise to instability in the financial system but also working as a factor limiting the influence of monetary policy" (Tak, 2002). This would lead to an increased need for central banks to acknowledge foreign currencies and policies in order to maintain control of its domestic monetary aggregates. Electronic money breaks down the barriers between countries and could one day lead to a universal currency backed by a commodity based basket of goods and services with universal price set in an auction market (Rahn2000). Decreased ability to control cross country currency exchanges lowers the central bank's control of the money supply.

The money multiplier is directly affected by the increased use of electronic money as a replacement for conventional currency. "When electronic money is introduced, currency decreases and deposit money increases as the private propensity to retain cash goes down. Therefore, the currency ratio is reduced, the money multiplier becomes larger, and the volume of money supply created from the supply of fixed reserve money is amplified" (Tak, 2002). This shows that electronic money will directly affect the money multiplier through the currency ratio.

Electronic money as well affects reserves. If reserve requirements are placed on electronic money balances, there is no change because it is assumed that currency will decrease by the same amount that electronic balances increase. However, this assumes that reserve requirements can be set on all electronic money balances. This is not the case when private institutions are liable for the smart cards and network money. If the central bank takes corrective action, it can limit the inflationary affects of increased money. Rahn feels that this will not be a problem as the changes will be slow and measurable, therefore allowing central banks to adjust appropriately (Rahn, 2000). If this assumption is overly optimistic about the central banks abilities it can be seen that the central bank could in fact lose control and inflation could result from increased use of privately issued electronic money.

Lastly, and probably the most agreed upon affect of electronic money is the loss of "seignorage" income: "the interest savings the government earns by issuing non-interest bearing debt in the form of currency" (Ely, 1996). This money is used to run the central bank and therefore the loss of it could cause central banks to suffer financially. This money is also used to fund the budget deficit and other government programs and the loss of this could hurt the government. This loss could be combated by treating electronic money balances similar to demand depos its and enforcing reserve requirements.

All of these effects are contingent, however, on the actual increased use of electronic money. Many experts feel that it will not replace currency due to its lack of security and the cost of implementing it.

The first of these concerns, lack of security, arises from the idea that fraud is increasingly possible with this technology. Anyone could manipulate technology to create a card or electronic balance that was not actually commodity backed. While currency is also fraudulently created, it is much more difficult to do base on the complexity of the currency system in most countries. A lack of security arises from the fear that network money balances can be controlled, stolen or manipulated by online hackers. Lastly, people may be unlikely to store large balances in electronic money for fear that a simple lost wallet could result in a loss of hundreds of dollars. Like currency, it is easily transferable and therefore could be considered unsafe for storing large sums of money (Ely, 1996). 
The cost of implementing widely used electronic money systems may limit the ir expansion as well. In order to expand the system, retailers and service organizations would have to pay to install systems that would allow them to accept this form of payment. Many may not be willing to do this when the current payment system seems sufficient. Unless it is made mandatory it seems unlike ly companies would pay the money to implement a system that just adds to the current transaction times and costs (Ely, 1996).

The future of electronic money is dependent on its growth, the regulation of it, and increased technological advancements that would increase the security of this new instrument. If in fact it does become widely used in the world it will directly impact the central bank's control of monetary policy unless the central bank includes it in its measurements of monetary aggregates and regulates its growth and usage.

\section{Conclusions}

1- This paper has reviewed the key features of electronic money and the main policy issues that arise. It notes that there is a wide range of potential issues, a number of which are of particular interest to central banks. At the same time, the development of e-money and the associated policy assessments discussed in the paper are subject to considerable uncertainty that is likely to influence the nature and timing of any regulatory response. Designing an appropriate regulatory framework for e-money involves balancing different objectives including the stability and financial integrity of the issuers, protection of consumers and the promotion of competition and innovation.

2- The recent evolution of the technology for financial transactions poses interesting questions for policymakers and financial institutions regarding the suitability of the current institutional arrangements and the availability of instruments to guarantee financial stability, effic iency, and effectiveness of monetary policy.

Regulatory concerns are raised by internet banking, electronic finance (e-finance), and e-money.

3- This paper argues that e-money, as a network good, could become an important form of currency in the future. Such a development would influence the effectiveness and implementation of monetary policy. If an increased use of e-money substantially limits demand for central bank reserves, it would require changes in the operational target of the central bank and a closer coordination of monetary and fiscal policies.

4- The increased use of electronic money will:

- Limit the central bank's ability to control money supply

- Increase the velocity of money

- Lower seignorage income

- Decrease reserves

- Decrease international monetary control

- Change the money multiplier

\section{Recommendations}

With respect to monetary policy effectiveness, level playing-field considerations and in order to address the regulatory concerns mentioned in this paper, the Central Banks in particular regards it as essential that the following requirements should be fulfilled: 
Effective supervision: issuers of electronic money must be subject to efficient supervision.

Solid and transparent legal arrangements: the rights and obligations on the part of the respective participants (customers, merchants, issuers and operators) in an electronic money scheme must be clearly defined and disclosed. Such rights and obligations must be enforceable under all relevant jurisdictions.

Technical security: electronic money schemes must maintain adequate technical, organizational and procedural safeguards to prevent contain and detect threats to the security of the scheme, particularly the threat of counterfeits.

Protection against criminal abuse: protection against criminal abuse, such as money laundering, must be taken into account when designing and implementing electronic money schemes.

Monetary statistics reporting: electronic money schemes must supply the central bank in each relevant country with whatever information may be required for the purposes of monetary policy.

Reserve requirements: the possibility must exist for central banks to impose reserve requirements on all issuers of electronic money.

\section{References}

Arnone, M., \& Bandiera, L. (2004, July). Monetary policy, monetary areas, and financial development with electronic money. International Monetary Fund, WP/06/122.

Berentsen, A. (1997). Digital money, liquid ity, and monetary policy. Retrieved from http://www.firstmonday.dk/issues/issue2 7/berentsen/

Bern kopf, M. (1998). Electronic cash and monetary policy. Risk management for electronic banking and electronic money activities. Basle Co mmittee on Banking Supervision.

Crockett, A. (1998, August). Report on electronic money. Bank for International Settle ments.

Ely, B. (1996). Electronic money and monetary policy: Separating fact from fiction. The Future of Money in the Information Age, CATO Institute's 14th Annual Monetary Conference. 23 May 1996. Retrieved fro $\mathrm{m}$ http://www.cato.org/moneyconf/14mc-2.html

Janson, N. (2004, July). The development of electronic money: Toward the emergence of free-banking. $W P / 04 / 122$.

Rahn, R. W.(2000). On the future of electronic pay ments. CATO Congressiona Testimony. 19 Sep. 2000. Retrieved fro $\mathrm{m}$ http://www.cato.org/testimony/ct-rr091900.html

Seign, G. (1996). E-money: Friend or foe of monetaris m. The Future of Money in the Information Age, CATO Institute's 14th Annual Monetary Conference. 23 May. 1996. Retrieved from http://www.cato.org/moneyconf/14mc-5.html

Tak, S-H. (2002, July). A study on the effects of the development of electronic money on monetary policy in Korea. Economic Papers, Bank of Korea, pp. 47-79. 


\section{Biographies}

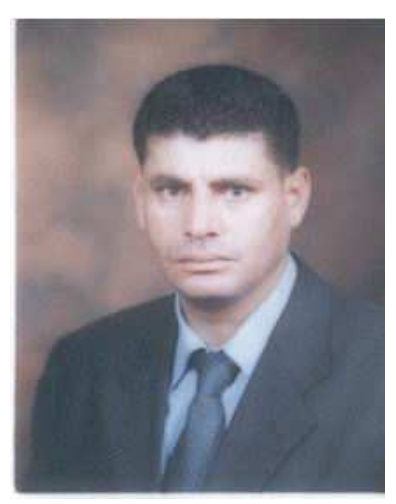

Mohamad Al-Laham, born in Jordan 1965, PHd in computer information system, Arab Academy for Banking and financial Sciences, Amman, Jordan. He is assistant professor in computer information system; $\mathrm{He}$ is an instructor in computer information system in Albalqa Applied University, Amman University College. His principal research interests include human computer interaction, e-commerce and web development.

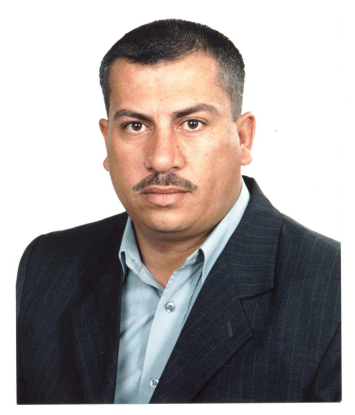

Haroon Al-tarawneh, born in Jordan 1970, PHd in computer information system, Arab Academy for Banking and financial Sciences, Amman, Jordan. He is assistant professor in computer information system, $\mathrm{He}$ is an instructor in computer information system in Albalqa Applied University, karak University College, Jordan. His principal research interests include software engineering, web Engineering (Agile Development, Extreme programming) and software process improvement. He is currently investigating how to implement software process improvements standards in small software development firms. He has published conference and journal papers in web development and software process improvement.

Najwan Abdallat is a student in MSc in the management information system, Arab Academy for Banking and Financial Sciences, Amman, Jordan. Her principal research interests include ecommerce and e-government. 